\title{
Aspekty ochrony konsumentów UE użytkujących waluty wirtualne
}

\begin{abstract}
Consumer protection in cryptocurrency transactions: The article provides an overview of consumer protection measures designed to ensure the rights of owners and users of virtual currencies. The authors state that there is an ongoing debate in the EU about the legal qualification of virtual currencies as financial instruments. It is contrary to the initial purpose of virtual currencies which was the payment function. The authors attempt to answer the question which EU law should cover the virtual currencies, MIFID2 or PSD2, as the legal qualification will be crucial for consumer rights. They claim that the position adopted by the European legislative should provide the fullest possible scope of consumer protection.
\end{abstract}

Słowa kluczowe: prawo europejskie, dyrektywa PSD2, dyrektywa MIFID2, ochrona konsumentów, waluty wirtualne, blockchain

Keywords: European law, PSD2 directive, MIFID2 directive, consumer protection, cryptocurrencies, blockchain

* Prawnik ds. fintech w GPN Data Europe Sp. z o.o., doktorant na Katolickim Uniwersytecie Lubelskim im. Jana Pawła II; e-mail: rpakla@gmail.com.

** Ekspert ds. technologii blockchain w Alior Bank SA'; e-mail: piotr.adamczyk@alior.pl.

\section{Wstęp}

Waluty wirtualne zostały uwzględnione w prawie UE w dyrektywie Parlamentu Europejskiego i Rady (UE) 2015/849 z 20 maja 2015 r. w sprawie zapobiegania wykorzystywaniu systemu finansowego do prania pieniędzy lub finansowania terroryzmu², gdzie zostały określone w art. 3 pkt 18 jako cyfrowe wyznaczniki

1 W niniejszym artykule P. Adamczyk jest autorem części Waluty wirtualne - aspekty techniczne.

2 Dyrektywa Parlamentu Europejskiego i Rady (UE) 2015/849 z 20 maja 2015 r. w sprawie zapobiegania wykorzystywaniu systemu finansowego do prania pieniędzy lub finansowania terroryzmu, zmieniająca rozporządzenie Parlamentu Europejskiego i Rady (UE) nr 648/2012 
wartości, które nie są emitowane ani gwarantowane przez bank centralny lub organ publiczny, nie muszą być powiązane z walutą prawnie obowiązującą i nie mają prawnego statusu waluty bądź pieniądza, lecz są akceptowane przez osoby fizyczne lub prawne jako środek wymiany i mogą być przekazywane, przechowywane lub sprzedawane drogą elektroniczną.

Europejski Bank Centralny (ECB) oraz Europejski Urząd Nadzoru Bankowego (EBA), Bank Rozrachunków Międzynarodowych w Bazylei (BIS) oraz Grupa Specjalna ds. Przeciwdziałania Praniu Pieniędzy (FATF) posługują się pojęciem walut wirtualnych. To pojęcie zastosował również Parlament Europejski w rezolucji z 26 maja 2016 r. w sprawie wirtualnych walut ${ }^{3}$. W pkt A tejże rezolucji Parlament Europejski z jednej strony powołał się na definicję wirtualnych walut stosowaną przez EBA: [waluty wirtualne są to] cyfrowe wyznaczniki wartości, które nie sa emitowane przez bank centralny ani organ publiczny, nie sa powiązane $z$ waluta fiducjarna i sa przyjmowane przez osoby fizyczne lub prawne jako środek płatniczy i moga być przekazywane, przechowywane badź sprzedawane drogq elektroniczna, z drugiej jednak stwierdził, że: waluty wirtualne opieraja się na technologii zdecentralizowanej księgi rachunkowej, która ułatwia wymianę i stanowi technologiczna podstawę ponad 600 systemów wirtualnych walut, i dostrzegł potencjał do osiągania przez te waluty wirtualne rangi walut globalnych. Parlament Europejski utożsamia wirtualne waluty z kryptowalutami, lecz mimo to stosuje termin „wirtualna waluta” zamiast terminu „kryptowaluta”4.

W tekście zdecydowano się używać pojęcia waluty wirtualne ze względu na zastosowanie tego terminu $\mathrm{w}$ polskich aktach prawnych w odniesieniu do omawianych instrumentów ${ }^{5}$. Jednocześnie należy przyznać rację poglądom przedstawianym w doktrynie, że polski ustawodawca powinien wzorem ECB używać zwrotu „waluty cyfrowe”, czyli polskiego odpowiednika pojęcia „digital currencies" jako dokładniejszego ${ }^{6}$.

i uchylająca dyrektywę Parlamentu Europejskiego i Rady 2005/60/WE oraz dyrektywę Komisji 2006/70/WE (tekst mający znaczenie dla EOG), Dz.Urz. UE L 141 z 5 czerwca 2015 r.

3 Rezolucja Parlamentu Europejskiego z 26 maja 2016 r. w sprawie wirtualnych walut, 2016/2007(INI), http://www.europarl.europa.eu/sides/getDoc.do?pubRef=-//EP// TEXT+TA+P8-TA-2016-0228+0+DOC+XML+V0//PL.

${ }^{4}$ W. Srokosz, Regulacje finansowe. FinTech - nowe instrumenty finansowe - resolution, Warszawa 2017, s. 40-42.

5 Zob. ustawa z 1 marca 2018 r. o przeciwdziałaniu praniu pieniędzy oraz finansowaniu terroryzmu (Dz.U. poz. 723), ustawa z 15 lutego 1992 r. o podatku dochodowym od osób prawnych (t.j. Dz.U. 2018 poz. 1036, ze zm.).

${ }_{6}$ Więcej zob. K. Piech, Leksykon pojęć na temat technologii blockchain oraz kryptowalut, https://www.gov.pl/documents/31305/0/leksykon_pojec_na_temat_technologii_ blockchain_i_kryptowalut.pdf/77392774-1180-79ab-4dd5-089ffab37602. 
Niniejszy artykuł zawiera próbę odpowiedzi na pytanie, jakie środki ochronne powinny być zastosowane względem konsumentów UE, którzy kupują waluty wirtualne, wymieniają je i korzystają z nich?

W Komisji ds. Gospodarczych i Monetarnych Parlamentu Europejskiego podczas prac nad niewielką nowelizacją dyrektywy Parlamentu Europejskiego i Rady 2014/65/UE z 15 maja 2014 r. w sprawie rynków instrumentów finansowych $^{7}$ europoseł Markus Ferber zgłosił poprawkę polegającą na objęciu walut wirtualnych zakresem stosowania dyrektywy MIFID2 ${ }^{8}$. Przedstawiona koncepcja ściera się z pierwotnym założeniem walut wirtualnych, które miały pełnić funkcję płatniczą. W niniejszym artykule autorzy przedstawią rozważania na temat wpływu wyboru jednej z powyższych koncepcji na prawa konsumentów posiadających i użytkujących waluty wirtualne. Autorzy spróbują odpowiedzieć, czy przepisy dotyczące walut wirtualnych powinny chronić interesy konsumentów zgodnie z dyrektywą MIFID2, czy też dyrektywą Parlamentu Europejskiego i Rady (UE) 2015/2366 z 25 listopada 2015 r. w sprawie usług płatniczych w ramach rynku wewnętrznego ${ }^{9}$. Za kryterium wartościujące autorzy wybrali rzeczywiste stosowanie przez konsumentów walut wirtualnych występujących w powszechnym obrocie. Głównym motywem powyższego wyboru jest fakt, że waluty wirtualne są wykorzystywane często niezgodnie z ich pierwotnymi założeniami (np. pełniąc funkcję dobra akumulującego wartość lub przedmiotu kolekcjonerskiego zamiast alternatywnej metody płatności). Dodatkowo należy wskazać, iż często funkcja płatnicza w zakresie walut wirtualnych doznaje ograniczeń ze względu na wczesne stadium ich adaptacji jako alternatywnego środka płatniczego. Wreszcie wahania wartości walut wirtualnych sprzyjają tendencjom konsumentów do traktowania ich jako aktywów inwestycyjnych. $Z$ drugiej jednak strony zauważalna jest tendencja do pojmowania walut wirtualnych jako alternatywnych środków płatniczych ${ }^{10}$. Dodatkowo, pojawiające się na rynku nowe spółki zaczynają oferować usługi wydawania kart płatniczych, które są jednocześnie „portfelami” określonych walut wirtualnych, umożliwiającymi dokonywanie płatności w walutach wir-

7 Dyrektywa Parlamentu Europejskiego i Rady 2014/65/UE z 15 maja 2014 r. w sprawie rynków instrumentów finansowych oraz zmieniająca dyrektywę 2002/92/WE i dyrektywę 2011/61/UE, OJ L 173 z 12 czerwca 2014 r., s. 349-496; dalej: dyrektywa MIFID2.

8 Komisja Gospodarcza i Monetarna, Poprawki 2-10, Rynki instrumentów finansowych, Wniosek dotyczący dyrektywy (COM(2018)0099-C8-0102/2018-2018/0047(COD)), Bruksela, 12 września 2018 r., 2018/0047(COD).

9 Dyrektywa Parlamentu Europejskiego i Rady (UE) 2015/2366 z 25 listopada 2015 r. w sprawie usług płatniczych w ramach rynku wewnętrznego, zmieniająca dyrektywy 2002/65/ WE, 2009/110/WE, 2013/36/UE i rozporządzenie (UE) nr 1093/2010 oraz uchylająca dyrektywę 2007/64/WE, OJ L 337, 23 grudnia 2015 r., s. 35-127; dalej: dyrektywa PSD2.

10 Zob. https://pl.scribd.com/document/372651554/2018-02-27-Umsatzsteuerliche-Behandlung-Von-Bitcoin-Und-Anderen-Sog-Virtuellen-Waehrungen\#from_embed. 
tualnych, które ulegają „przewalutowaniu” na walutę fiducjarną po określonym przez spółkę kursie ${ }^{11}$.

Niniejszy tekst podzielony jest na pięć jednostek redakcyjnych. W pierwszej autorzy skupili się na przedstawieniu, czym jest waluta wirtualna $\mathrm{w}$ aspekcie technicznym. Zamieszczony opis jest uproszczony ze względu na założenia niniejszej publikacji. Bardziej zaawansowane i szczegółowe opisy dostępne są w innych opracowaniach ${ }^{12}$. W drugiej części przedstawiono argumentację europosła M. Ferbera dotyczącą potrzeby objęcia dyrektywą MIFID2 walut wirtualnych. W trzeciej części autorzy dokonali analizy przepisów dyrektywy PSD2 w zakresie płatności walutami wirtualnymi. W czwartej - starali się odpowiedzieć na pytanie, czy z perspektywy ochrony konsumentów walut wirtualnych potrzebne są nowe regulacje? Na zakończenie, w części piątej, autorzy prezentują wnioski wynikające z przeanalizowanego materiału i przedstawiają swoje rekomendacje mające na celu zapewnienie jak najlepszej ochrony konsumentów walut wirtualnych.

\section{Waluty wirtualne - aspekty techniczne}

O walucie wirtualnej mówimy, gdy w ramach zdecentralizowanej sieci opartej na technologii blockchain (lub innej DLT ${ }^{13}$ ) przechowujemy rejestr transakcji związanych z cyfrowym odzwierciedleniem wartości. W uogólnieniu możemy uznać, że rejestr ten (najczęściej publiczny) przyporządkowuje każdej parze kluczy kryptograficznych (stanowiących swoisty identyfikator użytkownika w sieci opartej na technologii blockchain) „stan konta” w postaci liczby we wspomnianym wyżej rejestrze. Dokładny sposób przechowywania danych może się jednak poważnie różnić między konkretnymi implementacjami (np. między różnymi walutami wirtualnymi).

Historia zmian stanu konta poszczególnych użytkowników jest przechowywana jako transakcje i zawarta w blokach, a wewnętrzne porozumienie członków sieci, realizowane przez oprogramowanie komputerowe, jasno określa warunki, które musi spełnić transakcja, aby zostać uznana za poprawną i wykonaną (np. że w celu przesłania środków należy być ich właścicielem), a co za tym idzie zawartą w bloku, który zostanie uznany przez resztę sieci.

Modyfikacja oprogramowania, o ile pozwoli na ominięcie tych warunków, nie sprawi jednak, że transakcja zostanie zaakceptowana przez resztę sieci, lecz spowoduje rozgałęzienie łańcucha, tzw. fork.

11 Więcej zob. https://steemit.com/beyondbitcoin/@cryptowallet/crypto-debit-cards-token-card-vs-monaco-card-vs-tenx-card.

12 Więcej zob.: W.J. Luther, Cryptocurrencies, network, effects and switiching costs, Contemporarry Economy Policy nr 34, Morgantown 2016, s. 387-586; A.M. Antonopoulos, Mastering Bitcoin: Unlocking Digital Cryptocurrencies, O’Reilly, Sebastopol 2015; M. Swan, Blockchain: Blueprint for a New Economy, O'Reilly Media, Sebastopol 2015.

${ }_{13}$ Rozproszony rejestr transakcji, ang. distributed ledger technology. 
Łańcuchy walut wirtualnych mogą się trwale rozgałęzić w momencie zmiany w działaniu protokołu (implementacji aplikacji klienckiej sieci), która byłaby na tyle znacząca, że bloki powstałe na jego nowej wersji będą odrzucane przez starszą i vice versa. Jeżeli zdecydowana większość użytkowników zgodzi się przejść na nową wersję, nie ma wtedy większego problemu. Pojawia się on, gdy część użytkowników nie zgadza się z wprowadzoną zmianą. Powstaje wtedy sytuacja, w której w tym samym czasie istnieją dwa łańcuchy, które rozgałęziły się ze wspólnego początku i istnieją niezależnie. Zauważmy więc, że w obu łańcuchach istnieją teraz niezależnie jednostki waluty wirtualnej, które mogą zostać przetransferowane niezależnie.

Odpowiednikiem adresu konta w protokole zarządzającym walutą wirtualną jest najczęściej hash (skrót kryptograficzny nieodwracalny) klucza publicznego i to on jest podawany, gdy potrzebne jest ustalenie nadawcy bądź odbiorcy płatności. Dodając transakcję w sieci, użytkownik zwykle podaje, ile jednostek waluty wirtualnej (lub które konkretnie) chce przetransferować i na które konto powinny trafić. Kompletne dane transakcyjne są wtedy podpisywane cyfrowo za pomocą klucza prywatnego nadawcy płatności i podpisana transakcja zostaje rozpowszechniona w sieci.

Teoretycznie, w momencie zawarcia transakcji w bloku jest ona uznawana za dokonaną, lecz ze względu na specyfikę sieci blockchain i zagrożenia z nią związane, osoba przyjmująca płatność dla własnego bezpieczeństwa powinna poczekać, aż do łańcucha dołączone zostanie kilka kolejnych bloków. Minimalizuje to ryzyko, że blok, w którym zawarta była transakcja, zostanie odrzucony przez sieć. Dzieje się tak, ponieważ w większości sieci blockchain istnieje tzw. zasada najdłuższego łańcucha, w myśl której węzeł sieci zawsze używa najdłuższego poprawnego łańcucha, o którym ma wiedzę.

W dużej części obecnych walut wirtualnych obowiązuje pewien rodzaj opłat za umieszczenie transakcji w bloku. Nie są one obowiązkowe (i zazwyczaj użytkownik może sam dowolnie ustalić jej wartość), ale niedołączenie opłaty bądź dołączenie za niskiej może skutkować znacznym opóźnieniem w procesie zatwierdzenia transakcji lub nawet jej niezatwierdzeniem. Wynika to z faktu, że w celu ograniczenia liczby transakcji, zapobieganiu atakom na sieć oraz spowolnieniu rozrostu łańcucha zwykle istnieje pewnego rodzaju limit, który ogranicza liczbę transakcji, którą osoba wydobywająca jest w stanie zawrzeć w jednym bloku. Biorąc pod uwagę fakt, że duża część osób wydobywa nowe bloki dla zysku, wybierają oni te transakcje, które najbardziej opłaca im się zawrzeć w bloku (czyli te z największą opłatą transakcyjną). Ciągły napływ nowych transakcji oczekujących na zatwierdzenie powoduje, że możliwa jest sytuacja, w której będzie ich więcej niż możliwych do załączenia w danej chwili w bloku, a co za tym idzie, te z najmniejszą dołączoną opłatą transakcyjną nie zostaną w nim załączone. W trakcie czekania na następny blok może się okazać, że sytuacja będzie się powtarzać. 
W zależności od implementacji sieć może oferować różny poziom anonimowości swoim użytkownikom. Najpopularniejsze implementacje są jedynie pseudoanonimowe - ukrywają one tylko dane osób, które są właścicielami poszczególnych par kluczy kryptograficznych. Historia transakcji oraz stany konta powiązane $\mathrm{z}$ kluczami są $\mathrm{w}$ pełni jawne.

W momencie powiązania osoby z parą kluczy kryptograficznych jesteśmy w stanie uzyskać pełne informacje dotyczące przepływu waluty wirtualnej w obrębie jednej pary kluczy tej osoby. Należy jednak zaznaczyć, że z uwagi na stosunkowo łatwą i szybką generację pary kluczy jeden użytkownik sieci może posiadać ich w swoim portfelu wiele. Istnieją nawet specjalne rozwiązania, m.in. tzw. portfele HD (hierarchical deterministic wallet), które pozwalają generować nową parę kluczy dla każdej transakcji walutą wirtualną, a z uwagi na możliwość dowolnego łączenia i dzielenia transakcji w większości popularnych implementacji walut wirtualnych, zdecydowanie utrudnia to śledzenie operacji wykonywanych przez użytkownika, chyba że pozna się tzw. seed ${ }^{14}$ portfela, na podstawie którego generowane są klucze użytkownika. „Portfele HD” są obecnie powszechnym standardem i większość użytkowników (często nawet nieświadomie) z nich korzysta.

Ponieważ waluty wirtualne projektowane były od zawsze do istnienia wyłącznie w systemie informatycznym, nie mają one pewnych ograniczeń pieniądza fiducjarnego ${ }^{15}$. Podzielność jednej jednostki waluty wirtualnej jest definiowana przez jej twórców i zwykle jest dużo większa niż tradycyjnie - np. w przypadku sieci Bitcoin każda jednostka bitcoina dzieli się na 100000000 mniejszych jednostek zwanych satoshi, a w sieci Ethereum 1 ether dzieli się na 1000000000000000000 wei.

Wytwarzanie lub niszczenie waluty wirtualnej jest możliwe do zaprogramowania w obrębie aplikacji klienckiej sieci, na której oparta jest waluta wirtualna, lecz musi ono następować na określonych warunkach, które są znane i zaakceptowane przez wszystkich uczestników sieci. Zależnie od konkretnej implementacji technologii blockchain, możliwe są różne scenariusze, przykładowo:

- sieć może dążyć do posiadania z góry określonej, konkretnej sumy waluty wirtualnej w obiegu, a nowe jej jednostki są dystrybuowane co jakiś czas,

- suma jednostek wirtualnej waluty dąży do nieskończoności, a jej nowe jednostki są dystrybuowane co określony czas,

- sieć może posiadać stałą ilość waluty, która nigdy się nie zmienia.

${ }^{14}$ Ziarno generatora liczb losowych - ciąg znaków, na podstawie którego generowane są klucze kryptograficzne.

15 Pieniądz fiducjarny - waluta niemająca oparcia w dobrach materialnych, której wartość ma źródło z reguły w dekretowanym prawnie monopolu. Więcej zob. D. Cyman, Elektroniczne instrumenty płatnicze a bezpieczeństwo uczestników rynku finansowego, Warszawa 2013. 
Najczęściej nowe jednostki waluty wirtualnej są wytwarzane jako nagroda za poprawne dołączenie kolejnego bloku do łańcucha. Dzieje się tak np. w sieciach opartych na konsensusie proof of work ${ }^{16}$, takich jak Bitcoin czy Ethereum, gdyż obliczanie hashy danych (konieczne w celu dołączeniu bloku do łańcucha), potocznie określane jako „mining” lub „kopanie”, jest skomplikowane obliczeniowo, a przez to wymaga dużej mocy obliczeniowej, zasobów, a co za tym idzie również prądu i pieniędzy. Nowe jednostki są więc swoistym wynagrodzeniem za poświęcony czas i pieniądze uczestnika sieci.

Najpopularniejsze implementacje walut nie uwzględniają możliwości ich niszczenia, co nie oznacza, że jest to niemożliwe. $Z$ różnych przyczyn osoby odpowiedzialne za rozwijanie protokołów stojących za poszczególnymi walutami wirtualnymi uznały bezpośrednie rozwiązanie „zniszczenia” za niezgodne z ich wizją. Użytkownicy sieci w tym celu zwykle przesyłają jednostki waluty wirtualnej na nieistniejący adres, najczęściej złożony z samych zer. Należy jednak pamiętać, że jeżeli zostałaby kiedykolwiek wygenerowana para kluczy kryptograficznych, której klucz publiczny produkowałby adres złożony z samych zer, to byłyby do niej przypisane wszystkie „zniszczone” środki, a jej właściciel mógłby nimi rozporządzać (chyba że wcześniej przewidziano by takie zjawisko i postanowiono inaczej). Szansa na wystąpienie takiego zjawiska jest oczywiście ekstremalnie niska i bliska zeru, jednak nie jest to niemożliwe.

\section{Dyrektywa MIFID2 a waluty wirtualne}

Zdaniem europosła Markusa Ferbera dyrektywa MIFID2 powinna zostać uzupełniona o regulacje dotyczące walut wirtualnych. Europoseł w przytoczonym poniżej wniosku o uzupełnienie dyrektywy MIFID2 wskazał, że: wielu inwestorów indywidualnych posługuje się walutami wirtualnymi jako substytutami innych aktywów lub instrumentów finansowych. W przeciwieństwie do innych instrumentów finansowych waluty wirtualne sa $w$ dużej mierze nieuregulowane. W zwiazku z tym rynki wykorzystujące waluty wirtualne sa nieprzejrzyste, narażone na nadużycia na rynku i nie podlegaja podstawowym przepisom dotyczacym ochrony inwestorów. W zwiazku z powyższym należy uregulować waluty wirtualne jak instrumenty finansowe. Efektem zaproponowanej poprawki miałoby być wprowadzenie do dyrektywy MIFID2 art. 4 ust. 1 pkt 63a zawierającego definicję „walut wirtualnych" rozumianych jako waluty wirtualne określone w art. 1 pkt 2 lit. d dyrektywy Parlamentu Europejskiego i Rady 2018/843 ${ }^{17}$. Dodatkowo

16 Mechanizm konsensusu służący spowolnieniu powstawania nowych bloków za pomocą wymuszenia rozwiązywania skomplikowanej matematycznej zagadki w celu dołączenia bloku, aby zapobiec atakom na sieć.

17 Dyrektywa Parlamentu Europejskiego i Rady (UE) 2018/843 z 30 maja 2018 r. zmieniająca dyrektywę (UE) 2015/849 w sprawie zapobiegania wykorzystywaniu systemu finansowe- 
zaproponowano w załączniku I do sekcji C dyrektywy MIFID2 dodanie punktu w brzmieniu: 11a „waluty wirtualne”.

Przyjęcie powyższego rozwiązania skutkowałoby wprowadzeniem licznych wymogów określonych w dyrektywie MIFID2, w tym m.in. rozszerzonych obowiązków informacyjnych związanych z potrzebą badania świadomości inwestycyjnej konsumentów, polityki zleceń czy też zarządzania konfliktem interesów, jednocześnie utrudniałoby w znacznym zakresie rozwój walut wirtualnych poprzez konieczność uzyskania kosztownych licencji ${ }^{18}$. Należy przy tym mieć na względzie, że rynek walut wirtualnych w Europie dopiero się rozwija, a koszty prawne i znaczne wymogi kapitałowe stoją $\mathrm{w}$ jasnej sprzeczności $\mathrm{z}$ ideami stosowania walut wirtualnych, a tym samym modelami biznesowymi spółek, które świadczą usługi wymiany i sprzedaży walut wirtualnych. Prowadzenie działalności giełd wirtualnych mogłoby się zatem stać w niektórych przypadkach niemożliwe ze względu na konieczność odrzucania dużej części konsumentów w związku z wysokim lub bardzo wysokim ryzykiem związanym $\mathrm{z}$ wahaniami kursów walut wirtualnych. Należy podkreślić, że obecnie dyrektywa MIFID2 nie pozwala na uznanie, iż obrót walutami wirtualnymi jest działalnością inwestycyjną, gdyż waluty wirtualne nie są wymienione w sekcji A załącznika I do dyrektywy MIFID2, w którym znajduje wykaz usług inwestycyjnych i działalności inwestycyjnej ${ }^{19}$.

Zaproponowane rozwiązania wywołały ożywioną dyskusję w doktrynie. J. Czarnecki stwierdził, że propozycja europosła pozbawiona jest podstaw prawnych, a kryptowaluty (waluty wirtualne) mają zupełnie inną naturę niż produkty inwestycyjne ${ }^{20}$. Podobne stanowisko zostało przedstawione już wcześniej w doktrynie, gdzie stwierdzono unikalność walut wirtualnych ze względu na ich dualistyczny charakter ${ }^{21}$.

Zdaniem autorów objęcie walut wirtualnych dyrektywą MIFID2 nie stanowi rozwiązania optymalnego dla ich użytkowników. Należy wskazać, że szeroki poziom ochrony zapewniłby użytkownikom bezpieczeństwo, jed-

go do prania pieniędzy lub finansowania terroryzmu oraz zmieniająca dyrektywy 2009/138/ WE i 2013/36/UE, OJ L 156 z 19 czerwca 2018 r., s. 43-74.

${ }_{18}$ Więcej o ochronie konsumentów w zakresie instrumentów finansowych zob.: J. Cichorska, Misselling, czyli sprzedaż niepotrzebnych instrumentów finansowych i jej skutki. Stan prawny w Polsce $i$ Wielkiej Brytanii, https://rf.gov.pl/ru/wp-content/uploads/2017/08/ RU24_2.pdf; M. Lemonnier, Europejskie modele instrumentów finansowych, LEX nr 324820.

19 Zob. wyrok TSUE z 3 grudnia 2015 r. w sprawie o sygn. akt C-312/14, LEX nr 1927981.

${ }^{20} \mathrm{~J}$. Czarnecki, Cryptocurrency a financial instrument? A new proposal in the EU, https:// newtech.law/en/cryptocurrency-a-financial-instrument-a-new-proposal-in-the-eu/ [dostęp: 20 listopada 2018 r.].

${ }^{21}$ R. Bollen, The Legal Status of Online Currencies: Are Bitcoins the Future?, https://papers. ssrn.com/sol3/papers.cfm?abstract_id=2285247 [dostęp: 20 listopada 2018 r.]; F.M. Ametrano, Hayek Money: The Cryptocurrency Price Stability Solution, https://papers.ssrn.com/sol3/ papers.cfm?abstract_id=2425270 [dostęp: 20 listopada 2018 r.]. 
nakże konsekwencje wynikające z potrzeby posiadania znacznego kapitału i odpowiednich licencji, a także z realizowania wskazanych wyżej wymagań względem konsumentów, mogłyby spowodować, iż użytkownicy obciążeni wymaganiami wiedzy i weryfikacją jej znajomości oraz znacznymi kosztami (które prawdopodobnie powstałyby w wyniku przerzucenia ich przez pozostające na rynku nieliczne giełdy walut wirtualnych na konsumentów) straciliby zainteresowanie stosowaniem walut wirtualnych w ogóle. Jednocześnie autorzy świadomi są tego, że waluty wirtualne mają dla wielu konsumentów charakter inwestycyjny, jednak większość walut wirtualnych jest projektowanych w celach płatniczych. Wahania kursów większości walut wirtualnych mają charakter przejściowy i wynikają z kształtującego się dopiero rynku (m.in. na ceny walut wirtualnych mają doniesienia o wszelkich zmianach regulacyjnych ich dotyczących). W związku z powyższym należy krytycznie odnieść się do pomysłu uznania obrotu walutami wirtualnymi za działalność inwestycyjną, a biorąc pod uwagę potrzebę ochronnych konsumentów trzeba poszukiwać innych rozwiązań.

\section{Waluty wirtualne a dyrektywa PSD2 i ochrona konsumentów z niej wynikająca}

Zgodnie z art. 2 dyrektywa PSD2 ma zastosowanie do usług płatniczych świadczonych na terytorium Unii. Tytuły III i IV dyrektywy PSD2 mają zastosowanie do transakcji płatniczych w walucie państwa członkowskiego, gdy na terytorium Unii znajduje się zarówno dostawca usług płatniczych płatnika, jak i dostawca usług płatniczych odbiorcy lub jedyny dostawca usług płatniczych $w$ danej transakcji płatniczej. Tytuł III, z wyjątkiem art. 45 ust. 1 lit. b, art. 52 ust. 2 lit. e i art. 56 lit. a, oraz tytuł IV, z wyjątkiem art. 81-86, mają zastosowanie do transakcji płatniczych w walucie, która nie jest walutą państwa członkowskiego, gdy na terytorium Unii znajduje się zarówno dostawca usług płatniczych płatnika, jak i dostawca usług płatniczych odbiorcy lub jedyny dostawca usług płatniczych w danej transakcji płatniczej, w odniesieniu do tych części danej transakcji płatniczej, które są realizowane w Unii. Tytuł III, z wyjątkiem art. 45 ust. 1 lit. b, art. 52 ust. 2 lit. e, art. 52 ust. 5 lit. g i art. 56 lit. a, oraz tytuł IV, z wyjątkiem art. 62 ust. 2 i 4, art. 76, art. 77, art. 81, art. 83 ust. 1, art. 89 i art. 92, mają zastosowanie do transakcji płatniczych we wszystkich walutach, gdy tylko jeden z dostawców usług płatniczych znajduje się na terytorium Unii, w odniesieniu do tych części danej transakcji płatniczej, które są realizowane w Unii. Natomiast zgodnie $z$ art. 4 pkt 3 usługa płatnicza oznacza co najmniej jeden $\mathrm{z}$ rodzajów działalności gospodarczej wymienionych w załączniku I. Treści załącznika I odnoszą się do aktywności płatniczej związanej z użyciem pieniądza, $\mathrm{w}$ tym, zgodnie z pkt 25 preambuły, pieniądza elektronicznego w rozumieniu 
art. 2 pkt 2 dyrektywy 2009/110/WE 2 . Dyrektywa PSD2 nie odnosi się zatem do zastosowania walut wirtualnych.

Zdaniem autorów rozszerzenie dyrektywy PSD2 o waluty wirtualne nie jest odpowiednim rozwiązaniem. Mimo że waluty wirtualne pełnią funkcję płatniczą, to ich natura jest znacznie bardziej kompleksowa, a stosowanie mechanizmów ochronnych właściwych dla pieniądza elektronicznego i systemu płatności nie jest wystarczające chociażby ze względu na dynamiczną zmianę wartości, brak kursów wskazanych przez banki centralne, stosowanie nowego rodzaju instrumentów płatniczych. Waluty wirtualne nie powinny podlegać również dyrektywie PSD2 ze względu na samą swoją konstrukcję i dynamikę transakcji. Brak jest w tym przypadku możliwości zwrotu środków i blokowania transakcji oraz stosowania procedur reklamacyjnych właściwych dla pieniądza fiducjarnego. Podkreślenia wymaga fakt, że niektóre waluty wirtualne nie mają jasno określonego twórcy (np. bitcoin), a w związku z powyższym utrudnione byłoby chociażby dochodzenie roszczeń czy egzekwowanie swoich praw w trybach określonych przez dyrektywę PSD2.

Mając na względzie powyższe ustalenia, autorzy uznają, że dyrektywa PSD2 nie powinna zostać rozszerzona o zagadnienia związane $\mathrm{z}$ walutami wirtualnymi, gdyż system płatności i płatności walutami wirtualnymi zbyt od siebie odbiegają.

\section{Waluty wirtualne - potrzeba nowych regulacji?}

Ochrona interesów konsumentów wskazana została już w art. 169 Traktatu o funkcjonowaniu Unii Europejskiej jako jedna $\mathrm{z}$ kompetencji unijnych ${ }^{23}$. Prawidłowa regulacja zjawiska powinna opierać się na jego rzeczywistym charakterze. Definicja zamieszczona w dyrektywie w sprawie zapobiegania wykorzystywaniu systemy finansowego do prania pieniędzy lub finansowania terroryzmu nie uwzględnia w rzeczywistości tego, czym są waluty wirtualne, dokonując znacznej symplifikacji tego zjawiska i lekceważąc jego różnorodność.

Prawodawca europejski powinien przy tworzeniu różnego rodzaju regulacji skupiać się na możliwie dokładnej analizie zjawiska i dokonać podziału na:

- waluty wirtualne służące celom płatniczym,

- waluty wirtualne służące celom inwestycyjnym, tzw. ICO (Initial Coin Offering),

22 Dyrektywa Parlamentu Europejskiego i Rady 2009/110/WE z 16 września 2009 r. w sprawie podejmowania i prowadzenia działalności przez instytucje pieniądza elektronicznego oraz nadzoru ostrożnościowego nad ich działalnością, zmieniająca dyrektywy 2005/60/ WE i 2006/48/WE oraz uchylająca dyrektywę 2000/46/WE (tekst mający znaczenie dla EOG), OJ L 267 z 10 października 2009 r., s. 7-17, Special edition in Croatian: cz. 06, t. 011, s. 94-104.

${ }_{23}$ Wersja skonsolidowana Traktatu o funkcjonowaniu Unii Europejskiej, OJ C 326 z 26 października 2012 r., s. 47-390. 
- waluty wirtualne obowiązujące w systemach zamkniętych (np. wirtualne złoto w grach),

- wirtualne waluty/kryptowaluty niewymienialne na realne waluty.

Tylko rozszerzony podział walut wirtualnych pozwoli zapewnić należytą ochronę interesów gospodarczych konsumentów ze względu na fakt, że zakres ochrony konsumenta powinien wynikać przede wszystkim z charakteru usługi, a ta jest różna dla poszczególnych walut wirtualnych. Pomimo rozważań prowadzonych w Parlamencie Europejskim należy podkreślić, iż waluty wirtualne realizują również funkcję płatniczą, co potwierdza orzecznictwo TSUE, w którym stwierdzono, że wirtualna waluta $\mathrm{z}$ dwukierunkowym przepływem bitcoinów, która zostanie wymieniona na waluty tradycyjne w ramach transakcji wymiany, nie może być uznana za rzecz (w rozumieniu art. 14 dyrektywy Rady 2006/112/ WE z 28 listopada 2006 r. w sprawie wspólnego systemu podatku od wartości dodanej $^{24}$ ), ponieważ jej jedynym przeznaczeniem jest funkcja środka płatniczego. TSUE w orzeczeniu wyraźnie stwierdza, że waluty wirtualne stanowią umowny środek płatniczy, o ile jest to ich wyłączne zastosowanie ${ }^{25}$.

Waluty wirtualne zostały także masowo zaadaptowane i akceptowane przez przedsiębiorców (np. Samsung ${ }^{26}$, Medicover ${ }^{27}$ ).

Prawodawca europejski zdaje się pomijać znaczny wpływ na współczesne społeczeństwa krajów europejskich, jaki ma rozwój nowych technologii. $\mathrm{Z}$ podsumowania ostatniego międzynarodowego badania ING wynika, że 9\% konsumentów pochodzących z krajów europejskich wskazuje, że są właścicielami walut wirtualnych w marcu 2018 r. - w porównaniu z 8\% w Stanach Zjednoczonych i 7\% w Australii. Luksemburg i Belgia osiągnęły najniższy odsetek w Europie, podczas gdy 18\% w Turcji twierdzi, że posiada wirtualną walutę. Według R. de Besta wielu respondentów martwi się o ryzyko związane z inwestowaniem w waluty ${ }^{28}$. Znaczna i rosnąca skala zjawiska podkreśla zatem konieczność wprowadzenia odpowiednich regulacji, zapewniających odpowiednią ochronę konsumentów użytkujących waluty wirtualne.

Zapewnienie prawidłowej ochrony konsumentów powinno skutkować stworzeniem nowych przepisów regulujących również zasady odpowiedzialności cywilnej podmiotów świadczących usługi obrotu i płatności walutami wirtualnymi

${ }^{24}$ OJ L 347 z 11 grudnia 2006 r., s. 1-118.

25 Wyrok TSUE z 22 października 2015 r. w sprawie o sygn. akt C-264/14, http://curia. europa.eu/juris/document/document.jsf?docid=170305\&doclang=PL.

${ }^{26} \mathrm{Https} / / /$ bithub.pl/wiadomosci/samsung-akceptuje-kryptowaluty-na-litwie-lotwie-i-w-estonii/ [dostęp: 20 listopada 2018 r.].

${ }^{27} \mathrm{Https} / /$ cryptonews.pl/warszawskim-medicover-zaplacisz-bitcoinem-porod/ [dostęp: 20 listopada 2018 r.].

28 R. de Best, How Many Consumers Own Cryptocurrency?, https://www.statista.com/ chart/15137/how-many-consumers-own-cryptocurrency/. 
oraz określeniem odpowiednich obowiązków informacyjnych wobec konsumentów, wprowadzeniem systemu gwarancji, ochronę środków posiadanych w wirtualnych portfelach oraz odpowiedzialność podmiotów w zakresie dynamicznej zmiany wartości walut wirtualnych. Ten aspekt jest szczególnie istotny z tego względu, że tradycyjnie w systemie prawnym odpowiedzialność ponosi określony podmiot, natomiast w przypadku systemu walut wirtualnych nie ma podmiotu ponoszącego odpowiedzialność za jego funkcjonowanie, jeżeli tylko jest w pełni zdecentralizowany (mogą istnieć systemy tylko częściowo zdecentralizowane), jego twórca jest anonimowy (jak w przypadku bitcoina), kod oprogramowania systemu jest dostępny dla każdego, a samo oprogramowanie jest rozwijane przez tzw. społeczność. Nieuwzględnienie wymienionych aspektów będzie prowadziło do znacznego podniesienia ryzyka korzystania $z$ tego typu usług płatniczych.

W związku z powyższym wydaje się, że powstanie przepisów krajowych regulujących waluty wirtualne jest konieczne do czasu powstania wspólnych regulacji unijnych. Ochrona konsumenta zagwarantowana jest konstytucyjnie w wielu państwach UE (w Polsce art. 76 Konstytucji RP ${ }^{29}$ ) i wymaga wzmożonej aktywności prawodawcy krajowego, by zapewnić bezpieczeństwo obrotu. Skala powszechności walut wirtualnych różnego rodzaju pozwala stwierdzić, że pozostawienie obecnego stanu rzeczy może mieć fatalne skutki ekonomiczne dla dużej części konsumentów. Jednocześnie pewną aktywność ochronną podjął sektor bankowy, przez uniemożliwienie zakupu walut wirtualnych za pomocą kart kredytowych ${ }^{30}$.

Z uwagi na złożoność walut wirtualnych ścieżki rozwoju regulacji dla prawodawców krajowych są dwie. Pierwsza z nich to uznanie dualizmu walut wirtualnych i próba zakwalifikowania ich do usług quasi-płatniczych lub inwestycyjnych, z jednoczesnym narażeniem się na sprzeczność z prawem UE. Drugą możliwością jest stworzenie nowych regulacji, o charakterze ochronnym, które będą zawierać odpowiednie mechanizmy zabezpieczające dla konsumentów. Do takich mechanizmów należy z pewnością zaliczyć następujące obowiązki nałożone na dostawców/emitentów/sprzedawców walut wirtualnych:

- rozszerzone obowiązki informacyjne wobec konsumentów,

- wprowadzenie nowej instytucji nadzoru lub stworzenie specjalistycznych zespołów w ramach już działających urzędów,

- posiadanie odpowiednio wysokiego zabezpieczenia przez dostawcę w zależności od rozmiaru prowadzonej działalności,

- obowiązek rejestracji nowych walut wirtualnych oraz ich emitentów, które zostaną dopuszczone do obrotu w ramach krajowych instytucji zajmujących się obrotem walutami wirtualnymi,

${ }^{29}$ Konstytucja Rzeczypospolitej Polskiej z 2 kwietnia 1997 r., http://www.sejm.gov.pl/ prawo/konst/polski/kon1.htm.

${ }^{30} \mathrm{Https} / / / w w w . f o r b e s . c o m / s i t e s / n a e e m a s l a m / 2018 / 02 / 05 /$ banks-banning-cryptocurrency-purchase-on-credit-cards-why/\#1c237da73cf9 [dostęp: 20 listopada 2018 r.] 
- ustalenie systemu gwarancji i zabezpieczeń przed nagłą utratą wartości przez waluty wirtualne,

- obowiązek przedstawiania w sposób jasny i klarowny informacji w umowach ramowych lub jednorazowych o zakup/sprzedaż walut wirtualnych,

- obowiązek informowania o ryzyku związanym z zakupem walut wirtualnych, a nawet weryfikacja znajomości wiedzy konsumentów w zakresie zakupywanej waluty wirtualnej i poziomu ryzyka utraty środków, jakie wiąże się z zakupem,

- kontrola działalności reklamowej w zakresie walut wirtualnych,

- akcje edukacyjne dla konsumentów informujące o zaletach i ryzykach użytkowania walut wirtualnych,

- zapewnienie gwarancji w zakresie wysokości płatności walutami wirtualnymi (płatność może w sposób niezwykle dynamiczny zmienić swoją wartość w walucie fiducjarnej, która to zmiana nie może mieć wpływu na zakup konsumenta, a zwłaszcza skutkować koniecznością dopłaty lub zwrotu konsumentowi przez dostawcę w przypadku wzrostu wartości waluty wirtualnej względem waluty fiducjarnej, w której konsument uiścił opłatę, ze względu na potrzebę stabilności rynku),

- obowiązki audytowe względem dostawców portfeli walut wirtualnych pod względem zabezpieczeń.

Zaprezentowany wyżej katalog ma charakter otwarty i powinien być przez prawodawców krajowych cyklicznie uzupełniany w zależności od występujących na rynku zjawisk.

\section{Wnioski}

Zdaniem autorów zagadnienie ochrony konsumentów walut wirtualnych wymaga regulacji na poziomie ogólnoeuropejskim, ze względu na transgraniczny charakter tych walut. Stosowanie lokalnych przepisów ochronnych prowadziłoby wyłącznie do arbitrażu regulacyjnego giełd walut wirtualnych. Żadna z obecnie funkcjonujących regulacji nie jest odpowiednia do objęcia tematyki walut wirtualnych ze względu na fakt, że waluty wirtualne są zjawiskiem odrębnym od tradycyjnego systemu płatności, a ich charakter nie zawsze jest inwestycyjny. Ponadto bez wskazanego w niniejszym artykule podziału walut wirtualnych ze względu na ich rzeczywistych charakter, próba zbiorczego ujęcia całości zagadnienia w jednej z obecnie obowiązujących regulacji mogłaby doprowadzić do tego, że waluty wirtualne w grach komputerowych stałyby się regulowane $\mathrm{w}$ równym stopniu co instrumenty inwestycyjne.

Podsumowując, należy wskazać, że żadna z rozważanych regulacji, tj. dyrektywa MIFID2 oraz dyrektywa PSD2, nie może być w obecnym stanie prawnym podstawą do ochrony konsumentów walut wirtualnych. Poprawki zapropo- 
nowane przez europosła M. Ferbera nie mogą zapewnić odpowiedniej ochrony konsumentów, gdyż większość walut wirtualnych ze swojej natury nie ma charakteru inwestycyjnego. Jednocześnie żaden ze wskazanych wyżej aktów prawnych nie ma potencjału do jego modernizacji w taki sposób, by ochrona konsumenta walut wirtualnych była zapewniona w sposób komplementarny, gdyż akty te nie zostały zaprojektowane, by chronić konsumentów przed zagrożeniami wynikającymi ze stosowania alternatywnych metod płatności, jakimi są waluty wirtualne. Brak jest w obecnym europejskim systemie prawnym odpowiedniej regulacji w tym zakresie. Próby prac we wskazanych wyżej aktach mogą doprowadzić jedynie do przeregulowania walut wirtualnych w taki sposób, że większość giełd wycofa się z UE ze względu na znaczny wzrost kosztów funkcjonowania wynikający z konieczności uzyskania odpowiednich licencji i realizacji obowiązków przewidzianych dotychczas dla firm inwestycyjnych, a konsumenci zostaną zniechęceni do kupowania i używania walut wirtualnych z zawyżoną marżą. Zastosowane mechanizmy ochronne zarówno w dyrektywie PSD2, jak i MIFID2 są nieodpowiednie ze względu na pominięcie cech technologicznych walut wirtualnych, które powinny determinować charakter ochrony.

Zdaniem autorów wymagana jest szybka reakcja ze strony prawodawców krajowych w zakresie objęcia konsumentów walut wirtualnych ochroną na rynkach lokalnych do czasu wypracowania wspólnego podejścia w UE. Powyższe wynika z faktu, że popularność walut wirtualnych jest na tyle duża, że konsumenci powinni zostać objęci odpowiednimi przepisami chroniącymi przed utratą dostępu do środków w przypadkach nawet tak prozaicznych jak śmierć właściciela giełdy walut wirtualnych ${ }^{31}$.

Autorzy uważają, że celem prawodawcy europejskiego powinno być zapewnienie bezpiecznego i stabilnego rozwoju rynku walut wirtualnych wspieranego przez funkcjonowanie rzetelnych podmiotów w nim uczestniczących na zasadach konkurencji wolnorynkowej.

\section{Bibliografia}

\section{Artykuły naukowe}

Ametrano F.M., Hayek Money: The Cryptocurrency Price Stability Solution, https://papers.ssrn.com/sol3/papers.cfm?abstract_id=2425270.

Antonopoulos A.M., Mastering Bitcoin: Unlocking Digital Cryptocurrencies, O’Reilly Media, Sebastopol 2015.

de Best R., How Many Consumers Own Cryptocurrency?, https://www.statista.com/ chart/15137/how-many-consumers-own-cryptocurrency.

31 Więcej zob. https://cointelegraph.com/news/crypto-exchange-quadrigacx-missing-145-mln-after-death-of-founder. 
Bollen R., The Legal Status of Online Currencies: Are Bitcoins the Future?, https://papers. ssrn.com/sol3/papers.cfm?abstract_id=2285247.

Cichorska J., Misselling, czyli sprzedaż niepotrzebnych instrumentów finansowych i jej skutki. Stan prawny w Polsce i Wielkiej Brytanii, https://rf.gov.pl/ru/wp-content/ uploads/2017/08/RU24_2.pdf.

Cyman D., Elektroniczne instrumenty płatnicze a bezpieczeństwo uczestników rynku finansowego, Wolters Kulwer, Warszawa 2013.

Czarnecki J., Cryptocurrency a financial instrument? A new proposal in the EU, https:// newtech.law/en/cryptocurrency-a-financial-instrument-a-new-proposal-in-the-eu/.

Lemonnier M., Europejskie modele instrumentów finansowych, Warszawa 2017.

Luther W.J., Cryptocurrencies, network, effects and switiching costs, Contemporarry Economy Policy nr 34, Morgantown 2016.

Piech K., Leksykon pojęć na temat technologii blockchain oraz kryptowalut, https://www. gov.pl/documents/31305/0/leksykon_pojec_na_temat_technologii_blockchain_i_ kryptowalut.pdf/77392774-1180-79ab-4dd5-089ffab37602.

Srokosz W., Regulacje finansowe. FinTech - nowe instrumenty finansowe - resolution, Warszawa 2017.

Swan M., Blockchain: Blueprint for a New Economy, O’Reilly Media, Sebastopol 2015.

\section{Akty prawne}

Konstytucja Rzeczypospolitej Polskiej z 2 kwietnia 1997 r., http://www.sejm.gov.pl/prawo/konst/polski/kon1.htm.

Wersja skonsolidowana Traktatu o funkcjonowaniu Unii Europejskiej, OJ C 326, z 26 października 2012 r., s. 47-390.

Dyrektywa Parlamentu Europejskiego i Rady (UE) 2015/2366 z 25 listopada 2015 r. $\mathrm{w}$ sprawie usług płatniczych w ramach rynku wewnętrznego, zmieniająca dyrektywy 2002/65/WE, 2009/110/WE, 2013/36/UE i rozporządzenie (UE) nr 1093/2010 oraz uchylająca dyrektywę 2007/64/WE, OJ L 337 z 23 grudnia 2015 r., s. 35-127.

Dyrektywa Parlamentu Europejskiego i Rady (UE) 2015/849 z 20 maja 2015 r. w sprawie zapobiegania wykorzystywaniu systemu finansowego do prania pieniędzy lub finansowania terroryzmu, zmieniająca rozporządzenie Parlamentu Europejskiego i Rady (UE) nr 648/2012 i uchylająca dyrektywę Parlamentu Europejskiego i Rady 2005/60/ WE oraz dyrektywę Komisji 2006/70/WE (tekst mający znaczenie dla EOG), Dz.Urz. UE L 141 z 5 czerwca 2015 r.

Dyrektywa Parlamentu Europejskiego i Rady 2014/65/UE z 15 maja 2014 r. w sprawie rynków instrumentów finansowych oraz zmieniająca dyrektywę 2002/92/WE i dyrektywę 2011/61/UE, OJ L 173 z 12 czerwca 2014 r., s. 349-496.

Dyrektywa Parlamentu Europejskiego i Rady 2009/110/WE z 16 września 2009 r. w sprawie podejmowania i prowadzenia działalności przez instytucje pieniądza elektronicznego oraz nadzoru ostrożnościowego nad ich działalnością, zmieniająca dyrektywy 2005/60/WE i 2006/48/WE oraz uchylająca dyrektywę 2000/46/WE (tekst mający znaczenie dla EOG), OJ L 267 z 10 października 2009 r., s. 7-17. 
Dyrektywa Rady 2006/112/WE z 28 listopada 2006 r. w sprawie wspólnego systemu podatku od wartości dodanej, OJ L 347 z 11 grudnia 2006 r., s. 1-118.

Rezolucja Parlamentu Europejskiego z 26 maja 2016 r. w sprawie wirtualnych walut, 2016/2007(INI).

Komisja Gospodarcza i Monetarna, Poprawki 2-10, Rynki instrumentów finansowych, Wniosek dotyczący dyrektywy (COM(2018)0099-C8-0102/2018-2018/0047(COD)), Bruksela, 12 września 2018 r., 2018/0047(COD).

\section{Orzeczenia}

Wyrok TSUE z 3 grudnia 2015 r. w sprawie o sygn. akt C-312/14, LEX nr 1927981.

Wyrok TSUE 22 października 2015 r. w sprawie o sygn. akt C-264/14, http://curia. europa.eu/juris/document/document.jsf?docid=170305\&doclang=PL.

\section{Strony internetowe (stan na 20 listopada 2018 r.)}

Https://bithub.pl/wiadomosci/samsung-akceptuje-kryptowaluty-na-litwie-lotwie-i-w-estonii/.

Https://cryptonews.pl/warszawskim-medicover-zaplacisz-bitcoinem-porod/.

Https://www.forbes.com/sites/naeemaslam/2018/02/05/banks-banning-cryptocurrency-purchase-on-credit-cards-why/\#1c237da73cf9.

Https://pl.scribd.com/document/372651554/2018-02-27-Umsatzsteuerliche-Behandlung-Von-Bitcoin-Und-Anderen-Sog-Virtuellen-Waehrungen\#from_embed.

Https://cointelegraph.com/news/crypto-exchange-quadrigacx-missing-145-mln-after-death-of-founder. 